\title{
Assessment of serum lipid profile in early pregnancy and its relation with pre eclampsia: a prospective study
}

\author{
Kamlesh Kumari*, Urmila Singh, Shuchita Maharshi, Renu Singh
}

Department of Obstetrics \& Gynaecology, King George Medical University, Lucknow, UP, India

Received: 21 January 2016

Revised: 28 January 2016

Accepted: 17 February 2016

\section{*Correspondence:}

Dr. Kamlesh Kumari,

E-mail: drkk.bhu@gmail.com

Copyright: (c) the author(s), publisher and licensee Medip Academy. This is an open-access article distributed under the terms of the Creative Commons Attribution Non-Commercial License, which permits unrestricted non-commercial use, distribution, and reproduction in any medium, provided the original work is properly cited.

\section{ABSTRACT}

Background: Pathophysiology of pre eclampsia and atherosclerosis seems to be similar as a hyperlipidemic state, due to hormonal changes in pregnancy. We tried to assess the relationship between maternal plasma lipid concentration and risk of developing pre eclampsia.

Methods: This is a prospective cohort study, for a period of one year from August 2009 to August 2010. Total no of subjects $(\mathrm{N}=270)$ were divided into two groups: Control group: who remained normotensive during study and Study group: who developed pre-eclampsia.

Results: The mean level of cholesterol in study group was $(226.74 \pm 39.77 \mathrm{mg} / \mathrm{dl})$ significantly higher as compared to control group $(164 \pm 22.48 \mathrm{mg} / \mathrm{dl})$. That was statistically significant $(\mathrm{p}=0.001)$. Mean levels of cholesterol in mild PET group was $216 \pm 28.90 \mathrm{mg} / \mathrm{dl}$ and in severe PET group was $252.3 \pm 50.63 \mathrm{mg} / \mathrm{dl}$ respectively, that was also significantly higher as compared to control group $(\mathrm{p}=0.001)$. In our study mean levels of Triglyceride was $153.95 \pm 23.52 \mathrm{mg} / \mathrm{dl} \mathrm{in}$ control group and $205.25 \pm 42.48 \mathrm{mg} / \mathrm{dl}$ in study group. There were statistically significant difference between the groups $(\mathrm{p}=0.001)$. In mild PET mean value of Triglyceride was $198.99 \pm 36.12 \mathrm{mg} / \mathrm{dl}$ and in severe PET it was $220.35 \pm 53.13 \mathrm{mg} / \mathrm{dl}$. It was seen that both the study group had significantly higher mean value as compared to control group $(\mathrm{p}=0.001)$.

Conclusions: In present study we have observed that maternal dyslipidemia in early second trimester is associated with increased risk of developing pre eclampsia. So dyslipidemia in early second trimester is a very good predictor of pre eclampsia.

Keywords: Preeclampsia, Cholesterol, Triglyceride, Lipid profile

\section{INTRODUCTION}

Pre eclampsia is a major cause of maternal and fetal morbidity and mortality especially in developing countries. ${ }^{1,2}$ Despite considerable research, the aetiology of pre eclampsia remains unclear. Characteristic pathological lesions of pre eclampsia in uteroplacental bed are like necrotizing arteriopathy, accumulation of foam cells or lipid laden macrophages in decidua and fibroblast proliferation, similar to lesion found in atherosclerosis. Pathophysiology of pre eclampsia and atherosclerosis seems to be similar as a hyperlipidemic state, due to hormonal changes in pregnancy. ${ }^{3,4}$ So we intended this study to assess the relationship between maternal plasma lipid concentration and risk of developing pre eclampsia.

The aim and objectives of the study was to investigate the relationship between early pregnancy plasma lipid profile and risk of pre eclampsia during pregnancy. 


\section{METHODS}

This is a prospective cohort study, conducted in department of obstetrics and gynaecology, Queen Mary's Hospital, King George medical university, Lucknow for a period of one year from August 2009 to August 2010 in collaboration with the department of pathology, for biochemical analysis of serum lipid profile.

Normotensive women at the time of presentation with singleton pregnancy were included in the study with informed consent.

Women with any of the following were excluded: Diabetes mellitus, chronic hypertension or any other cardiovascular disease, smoker, history of thromboembolism, renal disease, liver disease, history of prior medical illness, any endocrinal disorder, multiple gestation, BMI >25, Age $>35 \mathrm{yr}$.

Detailed systemic and obstetrical examination was done. All routine investigation along with serum lipid profile was done including, Triglyceride (TG), Total Cholesterol (TC), HDL, LDL \& VLDL. All the subjects were normotensive at the time of enrolment and followed up for the development of pre eclampsia on the basis of systolic/diastolic blood pressure and urine albumin examination by dipstick method.

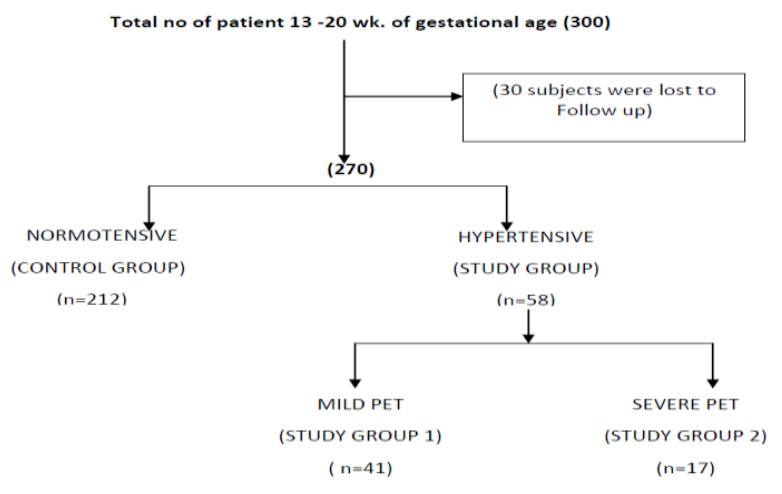

Figure 1: Study population.

Study population: Total no of subjects $(\mathrm{N}=270)$ were divided into two groups (Figure 1).

Control group: Those women who remained normotensive during study.

Study group: Those women who developed preeclampsia (PET). They were further divided into two groups:

- $\quad$ Mild PET: $B P \geq 140 / 90 \mathrm{mmHg}$ and urine albumin +1 (By dipstick method).

- $\quad$ Severe PET: $B P \geq 160 / 110 \mathrm{mmHg}$ and urine albumin $\geq$ +2 (By dipstick method).
The ANOVA test was used to compare the within group and between group variances amongst the study groups. ANOVA test provided " $F$ " ratio, where a higher " $F$ " value depicted a higher inter-group difference. To test the significance of two means the student ' $t$ ' test and chi square test was used.

\section{RESULTS}

As compared to control group the mean cholesterol levels in study group $(226.74 \pm 39.77 \mathrm{mg})$ was found to be significantly higher $(\mathrm{p}<0.001)$. It was seen that the mean cholesterol levels were minimum in control group (164.60 \pm 22.48$)$ followed by mild PET (216.12 \pm 28.90$)$. Mean cholesterol levels were found to be maximum $(252.3 \pm 50.63)$ in severe PET group (Table 1).

Table 1: Level of total cholesterol (mg/dl) in different groups.

\begin{tabular}{|lllll|}
\hline Group & $\begin{array}{l}\text { No. of } \\
\text { cases }\end{array}$ & Range & Mean & SD \\
\hline Control & 212 & $88.8-238$ & 164.60 & 22.48 \\
\hline Mild PET & 41 & $132-288.7$ & 216.12 & 28.90 \\
\hline Severe PET & 17 & $206-424$ & 252.33 & 50.63 \\
\hline
\end{tabular}

$\mathrm{F}=141.281 ; \mathrm{p}<0.001$

Table 2: Level of mean triglyceride (mg/dl) levels in different groups.

\begin{tabular}{|lllll|}
\hline Group & $\begin{array}{l}\text { No. of } \\
\text { cases }\end{array}$ & Range & Mean & SD \\
\hline Control & 212 & $88.2-206.7$ & 153.95 & 23.52 \\
\hline Mild PET & 41 & $126.3-282.2$ & 198.99 & 36.12 \\
\hline Severe PET & 17 & $124-340$ & 220.35 & 53.13 \\
\hline
\end{tabular}

$\mathrm{F}=78.138 ; \mathrm{p}<0.001$

Mean triglyceride level was found to be $153.95 \pm 23.52$ $\mathrm{mg} / \mathrm{dl}$ in control group and $205.25 \pm 42.48 \mathrm{mg} / \mathrm{dl}$ in study group, $198.99 \pm 36.12 \mathrm{mg} / \mathrm{dl}$ in mild PET group and $220.35 \pm 53.13 \mathrm{mg} / \mathrm{dl}$ in severe PET group. ANOVA test revealed statistically significant difference among groups $(\mathrm{F}=78.138 ; \mathrm{p}<0.001)$. The mean triglyceride levels in control group were found to be significantly lower as compared to that in study group $(\mathrm{p}<0.001)$. It was seen that both the study groups had significantly higher mean value as compared to control group $(\mathrm{p}<0.001)$ (Table 2).

All the lipid profile levels were found to be minimum in control group while TC, TG, HDL, VLDL and LDL were found to be maximum in severe PET group. TC/HDL and LDL/HDL were maximum in mild PET group (Table 3 and 4).

\section{DISCUSSION}

Pregnancy is associated with hyperestrogenemia, which is principal modulator of hyperlipidaemia. This process may be modulated by hyperinsulinism found in 
pregnancy. Several studies have been done by various authors to assess the serum lipid profile in early pregnancy and find out its relation with development of pre eclampsia. Vidyabati RK et al described that serum lipid profile in early second trimester can be used as predictor of pre eclampsia. ${ }^{5}$ Baker AM et al studied that maternal serum dyslipidaemia occur early in pregnancy in women with mild eclampsia. ${ }^{6}$ Takahashi WH et al studied the assessment of serum lipid in pregnant women aged over 35 years and their relation with pre eclampsia. ${ }^{7}$ Danial Enquabahrie et al. ${ }^{8}$ also described that plasma lipid concentration in early pregnancy and its relation with development of pre eclampsia. The observation of various studies have shown that maternal dyslipidaemia in early second trimester pregnancy associated with increased risk for development of pre eclampsia.

Table 3: Lipid profile levels in different groups.

\begin{tabular}{|c|c|c|c|c|c|c|}
\hline \multirow{3}{*}{$\begin{array}{l}\text { Variable } \\
\text { (mg/dl) }\end{array}$} & \multirow{2}{*}{\multicolumn{2}{|c|}{ Control $(n=212)$}} & \multicolumn{4}{|c|}{ Study Group (n=58) } \\
\hline & & & \multicolumn{2}{|c|}{ Mild $(n=41)$} & \multicolumn{2}{|c|}{ Severe $(n=17)$} \\
\hline & Mean & SD & Mean & SD & Mean & $\mathrm{SD}$ \\
\hline $\mathrm{TC}$ & 164.60 & 22.48 & 216.12 & 28.90 & 252.33 & 50.63 \\
\hline TG & 153.95 & 23.52 & 198.99 & 36.12 & 220.35 & 53.13 \\
\hline HDL & 38.15 & 11.42 & 38.74 & 18.10 & 41.86 & 12.85 \\
\hline VLDL & 30.79 & 4.70 & 39.80 & 22 & 44.07 & 10.63 \\
\hline LDL & 95.66 & 20.22 & 137.59 & 27.94 & 166.40 & 43.52 \\
\hline TC/HDL & 4.60 & 1.20 & 6.66 & 2.86 & 6.63 & 2.44 \\
\hline LDL/HDL & 2.73 & 0.98 & 4.41 & 2.30 & 4.45 & 1.98 \\
\hline
\end{tabular}

Table 4: Comparison of lipid profile in different groups.

\begin{tabular}{|c|c|c|c|c|c|c|}
\hline \multirow{2}{*}{$\begin{array}{l}\text { Variable } \\
\text { (mg/dl) }\end{array}$} & \multicolumn{2}{|c|}{ Control vs Mild PET } & \multicolumn{2}{|c|}{ Control vs Severe PET } & \multicolumn{2}{|c|}{ Mild vs Severe PET } \\
\hline & "t" & "p" & "t" & "p" & "t" & "p" \\
\hline $\mathrm{TC}$ & 12.786 & $<0.001$ & 13.648 & $<0.001$ & 3.443 & 0.001 \\
\hline TG & 10.175 & $<0.001$ & 9.863 & $<0.001$ & 1.776 & 0.081 \\
\hline HDL & 0.271 & 0.787 & 1.277 & 0.203 & 0.646 & 0.521 \\
\hline VLDL & 10.175 & $<0.001$ & 9.863 & $<0.001$ & 1.776 & 0.081 \\
\hline LDL & 11.360 & $<0.001$ & 12.382 & $<0.001$ & 3.013 & 0.004 \\
\hline TC/HDL & 7.618 & $<0.001$ & 6.054 & $<0.001$ & 0.047 & 0.962 \\
\hline LDL/HDL & 8.552 & $<0.001$ & 7.660 & $<0.001$ & -0.063 & 0.950 \\
\hline
\end{tabular}

In our study incidence of the pre eclampsia was $21.5 \%$. Hypertensive disorders affect $5-10 \%$ of all pregnancies. Out of this Preeclampsia develop $3-7 \%$ cases. In developed countries $16 \%$ maternal deaths occur due to hypertensive disorder. ${ }^{2}$

The subjects were included in this study aged 18-34 years. Most of the patients in all group were aged between 25-35 yrs. Mean age of control group was $25 \pm 3.21 \mathrm{yrs}$, in mild PET was 27.90 $\pm 3.25 \mathrm{yrs}$ and in severe PET was $27.53 \pm 3.68$ yrs .Proportion of higher age group is significantly higher in study group as compared to control group $(\mathrm{p}=0.024)$.

The mean level of cholesterol in study group was $(226.74 \pm 39.77 \mathrm{mg} / \mathrm{dl})$ significantly higher as compared to control group $(164 \pm 22.48 \mathrm{mg} / \mathrm{dl})$. That was statistically significant $(\mathrm{p}=0.001)$. Mean levels of cholesterol in mild
PET group was $216 \pm 28.90 \mathrm{mg} / \mathrm{dl}$ and in severe PET group was $252.3 \pm 50.63 \mathrm{mg} / \mathrm{dl}$ respectively, that was also significantly higher as compared to control group $(\mathrm{p}=0.001)$. However there was no statistically significant difference seen between two study groups i.e. mild and severe PET. This shows that if cholesterol levels were higher in early second trimester there was increased risk of developing pre eclampsia and severity of pre eclampsia was not directly proportional to levels of cholesterol.

Vidyabati RK et al found that total cholesterol mean values was $237.19 \pm 33.95 \mathrm{mg} / \mathrm{dl}$ in those subjects who developed pregnancy induced hypertension that was significantly higher as compared to Total cholesterol mean values $204.15 \pm 23.74 \mathrm{mg} / \mathrm{dl}$ of control group $(\mathrm{p}=0.000) .^{5}$ 
Baker AM et al stated that mean levels of total cholesterol higher in women who developed mild PET 219 \pm 36.0 $\mathrm{mg} / \mathrm{dl}$ as compared to control group who remain normotensive was $207 \pm 35.8 \mathrm{mg} / \mathrm{dl}$ respectively but it was not statistically significant $(\mathrm{p}=0.14) .{ }^{6}$ According to their study mean cholesterol values in severe PET was $191 \pm 21.6 \mathrm{mg} / \mathrm{dl}$ lower than control and mild PET. So according to them women with severe pre eclampsia had significantly less atherogenic lipid profile. Danial Enquabahrie et al according to them if levels of total cholesterol $>205 \mathrm{mg} / \mathrm{dl}$ then 3.60 fold increases risk of developing pre eclampsia. ${ }^{8}$

In our study mean levels of Triglyceride was $153.95 \pm 23.52 \mathrm{mg} / \mathrm{dl}$ in control group and 205.25 \pm 42.48 $\mathrm{mg} / \mathrm{dl}$ in study group. There were statistically significant difference between the groups $(\mathrm{F}=78.138, \mathrm{p}=0.001)$. In mild PET mean value of Triglyceride was $198.99 \pm 36.12$ $\mathrm{mg} / \mathrm{dl}$ and in severe PET it was $220.35 \pm 53.13 \mathrm{mg} / \mathrm{dl}$. It was seen that both the study group had significantly higher mean value as compared to control group $(\mathrm{p}=0.001)$ However, no statistically significant difference was seen between two study groups. This shows that if triglycerides levels are higher in early second trimester, there is increased risk of developing pre eclampsia and severity of pre eclampsia is not directly proportional to levels of triglycerides.

Vidyabati RK et al in their study Mean level of triglyceride was visibly higher $213.94 \pm 51.07 \mathrm{mg} / \mathrm{dl}$ in PIH group as compared to normotensive group $197.78 \pm 59.20 \mathrm{mg} / \mathrm{dl} .{ }^{5}$ However there was no statistically significant difference seen between two study group $(\mathrm{p}=0.059)$. Baker AM et al showed that mean value of Triglyceride in control group was $164 \pm 56.2 \mathrm{mg} / \mathrm{dl}$ and in mild PET group was $200 \pm 79.5 \mathrm{mg} / \mathrm{dl} .{ }^{6}$ Triglyceride level were $18 \%$ higher $(\mathrm{p}=0.02)$ in women with mild pre eclampsia compared with control subjects but in severe pre eclampsia mean value of Triglyceride $146 \pm 53.5 \mathrm{mg} / \mathrm{dl}$ was lower than control and mild PET $(p=0.25)$. Danial Enquabahrie et al according to them 4.15 fold increase risk of development of pre eclampsia if triglyceride levels was $>133 \mathrm{mg} / \mathrm{dl}^{8}$

As compared to control group the mean HDL levels in study group were found to be slightly higher, however the difference between two group was not to be significant statistically $(\mathrm{p}=0.426)$. Mean value in Control group was $38 \pm 11.42 \mathrm{mg} / \mathrm{dl}$. In mild PET group it was $38.74 \mathrm{mg} / \mathrm{dl}$ and in severe PET group it was 41.86 \pm 12.85 . Statistically, there was no significant intergroup difference $(\mathrm{p}=0.509)$.

According to this study mean levels of VLDL were lower $(30.79 \pm 4.70 \mathrm{mg} / \mathrm{dl})$ in control group as compared to study group $(41.05 \pm 8.50 \mathrm{mg} / \mathrm{dl})$. That was statistically significant $(\mathrm{p}<0.001)$. VLDL value was found to be higher in severe PET group $44.07 \pm 10.63 \mathrm{mg} / \mathrm{dl}$. It was seen that both the study group had significantly higher mean value as compared to control group
$(\mathrm{p}=0.001)$.However difference between two study group were not to be found significant.

According to our study mean LDL value in control group was $95.66 \pm 20.22 \mathrm{mg} / \mathrm{dl}$ and women who developed mild PET and severe PET had mean value of LDL was $137.59 \pm 27.94 \mathrm{mg} / \mathrm{dl}$ and $166.40 \pm 43.52 \mathrm{mg} / \mathrm{dl}$ respectively During comparison of these values showed that control group had significantly lower mean value as compared to both study group $(\mathrm{p}<0.001)$ while severe PET group had significant higher mean value as compared to mild PET group ( $\mathrm{p}=0.004)$.

We observed that mean value of TC/HDL ratio in control group was $4.60 \pm 1.2$, in mild PET was $6.66 \pm 2.86$ and in severe PET was $6.63 \pm 2.44$ respectively, control group had significantly lower mean value as compared to both the study group $(\mathrm{p}<0.001)$. No significant difference in mean TC/HDL ratio was seen between the two study group $(\mathrm{p}<0.05)$. This shows that $\mathrm{TC} / \mathrm{HDL}$ levels were higher in early second trimester there was increased risk of developing pre eclampsia.

The mean LDL/HDL ratio in control was 3.03 \pm 1.00 and in study group was $4.18 \pm 1.88$ that was significantly higher $(\mathrm{p}<0.001)$ as compared to control group. Mean levels of LDL/HDL in mild PET was 4.26 \pm 2.02 and in severe PET was 3.99 \pm 1.52 respectively, The mean level of LDL/HDL in both study group were found to be significantly higher as compared to control group $(\mathrm{p}<0.001)$. This shows that if LDL/HDL levels were higher in early second trimester there was increased risk of developing pre eclampsia.

\section{CONCLUSIONS}

In present study we have observed that maternal dyslipidaemia (TC, TG, VLDL, LDL, TC/HDL, LDL/LDL) in early second trimester is associated with increased risk of developing pre eclampsia. So dyslipidaemia in early second trimester is a very good predictor of pre eclampsia. We can improve feto-maternal out come by early detection of high risk patients. We cannot establish a causal relationship between dietary behaviour in pregnancy and the risk of preeclampsia, but our results suggest that by modification of dietary pattern we can help in prevention of pre eclampsia, however larger studies to be required to see dietary association with pre eclampsia.

\section{Funding: No funding sources Conflict of interest: None declared \\ Ethical approval: The study was approved by the Institutional Ethics Committee}

\section{REFERENCES}

1. Yadav S, Yadav R, Saxena S. Hypertensive disorder of pregnancy and perinatal outcome. The journal of obstetrics and gynaecology of India.1997;47:322-30. 
2. Gupta KB, Radhhvana I, Pal A, Premi HK, Ganeshan J. Perinatal outcome in pregnancy induced hypertension. Journal of the Indian medical association. 1996;94(1):6-16.

3. Murai JT, MuzYkankiy E,Taylor RN. Maternal and fetal modulator of lipid metabolism correlate with the development of pre eclampsia. Metabolism. 1997;46(8):963-7.

4. Chesley LC. Vascular reactivity in normal and toxemic pregnancy. Clin obstet gynaecol. 1966;6:871-81.

5. Vidyabati RK, Davina H, Singh NK, Singh W Gyaneshwar. Serum $\beta$ hcg and lipid profile in early second trimester as predictor of pregnancy induced hypertension. J obstet gynecol India 2010;60:44-50.

6. Takahashi WH, Martinelli S, Khoury MA. Assessment of serum lipid in pregnant women aged over 35 years and their relation with pre eclampsia. Einstein. 2008;6(1):63-7.

7. Auther Baker AM, Klein RL, Haeri S, Boggess K. Maternal serum dyslipidemia occurs early in pregnancy in women with mild but not severe preeclampsia. Am J Obstet Gynecol. 2009;4:201-93.

8. Enquobahrie D, Williams M,Carole B, Frederick I, Luthy D. Plasma lipid concentration in early pregnancy and risk of pre eclampsia. Am J Obstet Gynecol. 2003;189(6):106.

Cite this article as: Kumari K, Singh U, Maharshi S, Singh R. Assessment of serum lipid profile in early pregnancy and its relation with pre eclampsia: a prospective study. Int J Reprod Contracept Obstet Gynecol 2016;5:840-4. 